\title{
ANALISIS FAKTOR PENDORONG DAN PENARIK WISATAWAN MILLENNIAL BERKUNJUNG KE KUTA SELATAN
}

\author{
I Putu Saiban Sugiartawan ${ }^{1}$, LGLK. Dewi ${ }^{2}$, NGAS. Dewi ${ }^{3}$ \\ ${ }^{1}$ Email: saibansugiartawan@yahoo.com \\ Program Studi Industri Perjalanan Wisata, Fakultas Pariwisata, Universitas Udayana \\ 2Email: leli_ipw@unud.ac.id \\ Program Studi Industri Perjalanan Wisata, Fakultas Pariwisata, Universitas Udayana \\ 3Email: susrami_ipw@unud.ac.id \\ Program Studi Industri Perjalanan Wisata, Fakultas Pariwisata, Universitas Udayana
}

\begin{abstract}
Millennial tourists are the most potential tourists at the moment because of their number in the world. Kuta Selatan is one of the well-known and attractive districts for millennials visiting Bali. Therefore the purpose of this study is to determine the push and pull factors of millennial tourists visiting South Kuta and what factors are dominantly encouraging and attracting tourists to visit South Kuta. This research uses descriptive quantitative data analysis which is processed using SPSS 18.0 for windows application. The sample was determined purposively by 200 millennial tourists visiting South Kuta. Data collection techniques were carried out by means of observation, questionnaires, interviews, literature studies, and documentation. Data analysis techniques are the validity test, reliability test, and factor analysis. The results showed that there were four push factors ecourage millennial tourists to visit South Kuta, namely: trying a new lifestyle, breaking away from boredom, friends or family and increasing self-esteem and five factors attracting millennial tourists visiting South Kuta, namely: factors the symptoms of Kuta Selatan, culture and tradition, price, variety of nightlife and clean, cool air. Based on the analysis it is known that the factor of trying a new lifestyle becomes the dominant factor that ecourage millennial tourists to visit South Kuta with an eigenvalue of 4.370 and a variance percentage of $29.133 \%$ while the viral factor of South Kuta becomes the dominant factor that attracts millennial tourists visiting South Kuta with a value eigenvalue of 6.788 and the total percentage of variance of $29.512 \%$.
\end{abstract}

\begin{abstract}
Abstrak: Wisatawan millennial merupakan wisatawan yang paling potensial pada saat ini karena jumlah mereka di dunia. Kuta Selatan merupakan salah satu Kecamatan yang terkenal dan menarik bagi para millennial yang berkunjung ke Bali. Oleh karena itu tujuan dari Studi ini adalah untuk mengetahui faktor pendorong dan penarik wisatawan millennial berkunjung ke Kuta Selatan serta faktor apa saja yang dominan mendorong dan menarik wisatawan untuk berkunjung ke Kuta Selatan. Studi ini menggunakan analisis data deskriptif kuantitatif yang diolah dengan menggunakan aplikasi SPSS 18.0 for windows. Sampel ditentukan secara purposive berjumlah 200 orang wisatawan millennial yang berkunjung ke Kuta Selatan. Teknik pengumpulan data dilakukan dengan cara observasi, kuesioner, wawancara, studi kepustakaan, dan dokumentasi. Teknik analisis data adalah uji validitas, uji reliabilitas, dan analisis faktor. Hasil studi menunjukkan bahwa terdapat empat buah faktor pendorong yang mendorong wisatawan millennial berkunjung ke Kuta Selatan yaitu: mencoba gaya hidup baru, melepaskan diri dari rasa jenuh, teman atau keluarga serta maningkatkan harga diri dan lima faktor penarik wisatawan millennial berkunjung ke Kuta Selatan yaitu: faktor viralnya Kuta Selatan, budaya dan tradisi, harga, variasi hiburan malam serta udara yang bersih dan sejuk. Berdasarkan hasil analisis diketahui bahwa faktor mencoba gaya hidup baru menjadi faktor dominan yang mendorong wisatawan millennial berkunjung ke Kuta Selatan dengan nilai eigenvalue sebesar 4,370 dan persentase variance sebesar 29,133\% sedangkan faktor viralnya Kuta Selatan menjadi faktor dominan yang menarik wisatawan millennial berkunjung ke Kuta Selatan dengan nilai eigenvalue sebesar 6,788 dan total persentase variance sebesar $29,512 \%$.
\end{abstract}

Keywords: push and pull factor, millennial tourist, factor analysis, kuta selatan. 


\section{PENDAHULUAN}

Wisatawan millennial merupakan wisatawan yang lahir dan tumbuh berkembang bersamaan dengan perkembangan teknologi yang ada. Fenomena yang terjadi pada saat ini adalah terdapat banyak wisatawan muda yang berkunjung ke suatu daerah diluar daerah asalnya. Hal ini terjadi akibat pergeseran generasi yang telah terjadi dari generasi $\mathrm{X}$ menjadi genarasi $\mathrm{Y}$ atau yang biasa disebut dengan generasi millennial. Saat ini traveling sudah menjadi salah satu kegiatan yang sedang diminati banyak kalangan, khususnya para generasi millennials. Menurut Ryder (1965) mengatakan generasi adalah sebuah kelompok yang terdiri dari individu dengan kisaran umur yang sama yang telah mengalami peristiwa sejarah yang sama dalam periode waktu yang sama.

Salah satu tempat tujuan wisatawan millennial di Indonesia adalah Pulau Bali yang merupakan tempat wisata terbaik di Dunia. Berdasarkan majalah Travel and Leisure World's Best Award yang mengatakan bahwa Bali menempati urutan kedua setelah Kepulauan Galapagos dan menempati tempat pertama di Asia tahun 2016, di tahun berikutnya tepatnya tahun 2017 Bali kembali menyabet tempat pertama untuk destinasi wisata terbaik versi Trip Advisor dengan mengalahkan Paris, dan di tahun 2018 Bali tetap masuk kedalam destinasi terbaik dunia versi Trip Advisor dan berada di posisi keempat. Faktor terkenalnya Bali di dunia tersebut menjadi motivasi bagi wisatawan untuk berkunjung untuk berlibur atau menghabiskan waktu luang yang dimilikinya.

Menurut Sutrisno (2013:109) motivasi adalah faktor yang mendorong seseorang untuk melakukan suatu aktivitas tertentu, motivasi sering kali diartikan sebagai faktor pendorong perilaku seseorang. Sedangkan menurut Schiffman dan Kanuk (2000:69) dalam Wahyuni (2008), motivasi merupakan sebuah kekuatan penggerak yang terdapat di dalam diri seseorang. Motivasi wisatawan millennial untuk berwisata ke Bali didominasi oleh keinginan untuk mencari atau mempelajari hal-hal yang baru, pencarian jati diri, variasi tempat wisata, dan sebagai pengembangan dirinya sendiri. Hal tersebut didapat berdasarkan hasil penelitian yang dilakukan oleh Parhusip (2018) yang berjudul "wisatawan milenial ke Bali".
Kabupaten Badung merupakan kabupaten terpopuler di Bali dan banya dikunjungi oleh wisatawan luar Bali. Sejak 5 tahun terakhir jumlah kunjungan wisatawan selalu meningkat walaupun pertumbuhannya mengalami fluktuasi yang diakibatkan oleh krisis keuangan serta bencana alam.

Kuta Selatan merupakan wilayah yang hingga kini lebih dikenal dengan daya tarik wisata Pura Uluwatu dan Garuda Wisnu Kencana yang memiliki unsur budaya. Hal ini dapat terlihat dari monumen Garuda Wisnu Kencana yang kini sudah menjadi landmark pariwisata Bali yang disebut sebagai patung salah satu patung tertinggi di dunia dan juga tari kecak di Pura Luhur Uluwatu. Selain budaya, Kuta Selatan kini sudah berkembang menjadi wisata pantai yang mulai terekspos ke wisatawan mancanegara dan nusantara karena Pantai di Kuta Selatan dikelilingi ole tebingtebing yang indah dan menjadi tempat yang instagramable. Instagramable merupakan sebuah istilah tempat wisata yang sering dijadikan sebagai tempat berfoto dan diunggah ke media sosial instagram. Potensi yang dimiliki oleh Kuta Selatan selalu terjaga hingga saat ini. Kuta Selatan juga dikenal sebagai kawasan dengan fasilitas yang lengkap di Bali. Dimulai dari kemudahan mencari tempat menginap dari yang murah hingga yang mewah, mudah mencari tempat makan yang menyajikan makanan lokal dan internasional, serta aktivitas wisata yang paling disukai wisatawan seperti jalan-jalan ke pantai, berenang, berselancar, olah raga air dan juga clubbing. Semua hal ini yang secara tidak langsung sudah menjadikan Kuta Selatan kini sebagai tempat wisata yang wajib dikunjungi oleh para wisatawan terutama wisatawan millennial yang berkunjung ke Bali.

Oleh karena itu studi tentang analisis faktor pendorong dan penarik wisatawan millennial berkunjung ke Kuta Selatan ini perlu dilakukan untuk mengetahui dan memahami bagaimana karakteristik serta motivasi berkunjung para millennial untuk melakukan sebuah perjalanan ke daerah tujuan wisata yang ada di Bali secara umum dan Kuta Selatan secara khususnya.

\section{METODE}

Studi ini dilakukan untuk mengetahui faktor pendorong dan penarik wisatawan millennial berkunjung ke Kuta Selatan serta faktor pendorong dan penarik apa yang paling 
mendominasi wisatawan millennial untuk berkunjung ke Kuta Selatan. Variabel yang digunakan adalah variabel karakteristik wisatawan serta variabel motivasi berkunjung yang dibagi menjadi dua sub variabel yaitu sub variabel faktor pendorong meliputi: Escape, Relaxation/Hobbies, Prestige, Enhancement of Kinship Relationships, Novelty (Yuan \& Mcdonald dalam Lay, 2013). Serta sub variabel faktor penarik meliputi: Culture and History, Cosmopolitan Environment, Wilderness, Facilities, Hunting, Ease to Travel, Budget, Electronic Word of Mouth (Yuan \& Mcdonald dalam Lay, 2013) dan (Goyette, et all, 2010).

Untuk mendapatkan data dalam studi ini digunakan beberapa teknik pengumpulan data antara lain: observasi, kuisioner, wawancara, kepustakaan, dokumentasi. Studi ini menggunakan kuisioner yang dibagikan kepada wisatawan millennial mancanegara dan nusantara yang berkunjung ke Kuta Selatan. Penentuan jumlah sampel menggunakan teori dari Hair, et al (2006). Yaitu jumlah indikator variabel observasi dikalikan 5 atau 10.

Dalam studi ini terdapat dua sub variabel yaitu faktor pendorong dan faktor penarik. Kedua sub variabel ini kemudian dipecah menjadi 39 sub indikator. Untuk mendapatkan jumlah responden maka jumlah pertanyaan dikalikan 5 atau 10. Dalam hal ini, peneliti memilih jumlah pertanyaan dikalikan 5 adalah $5 \times 39=195$ dibulatkan menjadi 200 . Jadi, total responden dalam studi ini sebanyak 200 orang. Kuesioner dibagikan secara purposive kepada 200 orang wisatawan millennial yang berkunjung ke Kuta Selatan.

Teknik analisis data yang digunakan pada studi ini adalah analisis deskriptif kuantitatif. Metode ini dilakukan untuk mengungkapkan faktor pendorong dan penarik wisatawan millennial berkunjung ke Kuta Selatan dengan penyebaran kuesioner kepada wisatawan millennial yang yang sedang berkunjung ke Kuta Selatan. Kemudian dilakukan teknik analisis data dengan mengolah data melalui program SPSS versi 18.0 for windows. Adapun penjabaran pengolahan data analisis faktor terdiri atas: uji validitas, uji reliabilitas, serta tahap analisis faktor yang digunakan yaitu: uji KMO dan bartlett's test, uji Measure of sampling adequacy (MSA), menentukan jumlah faktor, rotasi faktor, dan interpretasi faktor.

\section{HASIL DAN PEMBAHASAN}

Kecamatan Kuta Selatan merupakan sebuah kecamatan yang terletak di daerah paling selatan Pulau Bali dan merupakan salah satu kecamatan dari enam kecamatan yang ada di Kabupaten Badung. Kuta Selatan merupakan daerah tujuan wisata terkenal yang ada di Bali. Kuta Selatan dikenal karena memiliki potensi keindahan alam, keindahan atraksi wisata, fasilitas berupa nightclub serta café-café yang sangat memanjakan wisatawan, aktivitas wisata yang menarik, serta adat dan budayanya. Letak geografis dari Kuta Selatan tepatnya berada antara $8^{\circ} 46^{\prime} 58.7^{\prime \prime}$ LS dan $115^{\circ} 05^{\prime} 00^{\prime \prime}-115^{\circ} 10^{\prime} 41.3^{\prime \prime}$ BT yang berbatasan langsung dengan Kecamatan Kuta di bagian utara serta Samudra Hindia di bagian timur, selatan, dan barat dan Kuta Selatan memiliki ketinggian sekitar 28 meter di atas permukaan laut. Kuta selatan memiliki curah hujan 1,275 $\mathrm{mm}$ per tahun serta sebagian besar wilayah Kuta Selatan merupakan daerah perbukitan batu kapur yang dikelilingi oleh pantai dengan luas mencapai 101,13 km2.

\section{Karakteristik Wisatawan Millennial}

Lebih didominasi oleh wisatawan mancanegara asal Jerman sebesar 18\%. Hal ini dapat terjadi karena wisatawan Jerman cenderung memiliki sikap sperti ingin mengetahui suatu hal baru hingga tuntas, tertarik pada kebudayaan yang bersifat tradisional, dan menyukai tempat wisata dengan alam yang indah dan menarik. Sedangkan untuk wisatawan nusantara didominasi oleh wisatawan yang berasal dari Jawa Timur sebesar 19\%. Hal ini dapat terjadi karena jarak antara Jawa Timur dan Bali yang cukup dekat bagi wisatawan luar Bali yang ingin melakukan kegiatan wisata secara overland.

Karakteristik wisatawan millennial yang paling banyak menurut jenis kelaminnya adalah perempuan sebesar $53 \%$. Hal ini terjadi karena wisatawan yang berjenis kelamin perempuan merupakan wisatawan yang lebih konsumtif dan memiliki kecenderungan berkunjung ke kawasan wisata untuk melakukan selfie dengan menggunakan akun media sosial yang dimilikinya dengan tujuan untuk menunjukkan eksistensi saat berkunjung ke daya tarik wisata yang viral.

Berstatus masih belum menikah sebanyak $86,5 \%$. Hal ini dapat terjadi karena wisatawan millennial yang masih berstatus 
belum menikah memiliki waktu luang dan santai yang lebih banyak sehingga dapat lebih memaksimalkan waktu luang yang dimiliki untuk menikmati berwisata bersama dengan saudara, teman, maupun berwisata sendiri

Masih berusia 19 sampai 25 tahun sebanyak 69\%. Hal ini berhubungan dengan karakteristik status dari wisatawan millennial tersebut. Usia 19 sampai 25 tahun lebih banyak didominasi oleh wisatawan millennial yang belum menikah di usia muda dengan status yang masih single membuat wisatawan millennial tersebut memiliki waktu luang yang banyak dan lebih leluasa untuk memanfaatkan waktu luang yang ada untuk berwisata.

Lebih banyak bekerja sebagai pelajar sebesar $57 \%$. Hal ini dapat terjadi karena wisatawan millennial yang masih berprofesi sebagai pelajar memiliki sikap yang sangat senang berpergian, sadar akan teknologi, memiliki waktu luang yang cukup untuk berwisata serta memiliki ras ingin tahu yang tinggi untuk mengunjungi suatu tempat yang menarik ataupun yang sedang berkembang menjadi tempat wisata yang mulai dikenal dunia.

Memiliki tingkat pendidikan sebagai siswa SMA/SMK sebanyak 55,5\%. Hal ini berhubungan dengan karakteristik usia dan status dimana wisatawan millennial yang memiliki tingkat pendidikan sebagai siswa SMA/SMK memiliki rasa ingin tahu yang tinggi terhadap suatu hal, memiliki sikap untuk menunjukkan eksistensi terhadap suatu hal, memiliki waktu luang atau weekend yang dapat digunakan untuk berwisata serta mengerti penggunaan teknologi dan media sosial yang menjadi faktor bagi mereka untuk berkunjung ke suatu daerah dengan daya tarik wisata yang indah dan instagramable.

Memiliki waktu berlibur lebih dari 7 hari sebesar $65 \%$. Hal ini dapat terjadi karena terdapat banyak daya tarik wisata budaya dan pantai di Kuta Selatan yang tidak mungkin dapat dikunjungi dalam satu hari saja. Selain itu, sebagaian besar wisatawa millennial yang berkunjung ke Kuta Selatan memiliki ketertarikan untuk mengunjungi daya tarik wisata yang ada disekitar daerah wisata yang dikunjungi.

Besar pengeluaran perhari kurang dari Rp. 500.000 sebesar 43,5\%. Hal ini dapat terjadi karena wisatawan millennial yang berkunjung ke Kuta Selatan merupakan wisatawan yang masih peduli dengan pengeluaran keuangan yang dimilikinya. Sehingga banyak wisatawan millennial yang lebih memilih untuk mengeluarkan biaya kurang dari Rp. 500.000 per hasrinya saat berkunjung ke Kuta Selatan.

Lebih banyak menggunakan homestay sebagai tempat menginap sebesar $31,5 \%$. Hal ini terjadi karena tarik yang dikeluarkan oleh wisatawan millennial yang menggunakan homestay lebih terjangkau jika dibandingkan dengan Hotel dan Villa.

Lebih banyak menginap di daerah Kuta sebesar 24\%. Hal ini dapat terjadi karena jarak antara Kuta Selatan dengan Kuta sejauh 14 km atau sekitar 25 menit perjalanan menggunakan kendaraan bermotor.

Lebih memilih untuk menggunakan sepeda motor saat berkunjung ke Kuta Selatan sebesar $62,5 \%$. Hal ini dapat terjadi karena sepeda motor merupakan kendaraan yang mudah digunakan dan mudah didapatkan yang mudah dijumpai di beberapa tempat di sekitar Hotel atau tempat menginap wisatawan millennial tersebut. Disamping itu, harga yang dikeluarkan untuk menyewa sepeda motor lebih terjangkau dibandingkan dengan menyewa mobil.

Pantai Dreamland menjadi daya tarik wisata terfavorit dengan pilihan sebanyak 20\%. Hal ini dapat terjadi karena Pantai Dreamland merupakan pantai yang sangat popular dan mudah dikenal oleh wisatawan yang berkunjung ke Kuta Selatan. Selain itu pantai dengan ombak biru, cuaca yang bagus, akses yang sangat mudah dijangkau dan pasir putih yang ada menjadikan Pantai Dreamland sebagai daya tarik wisata yang cocok untuk kegiatan berjalan-jalan, berjemur, berselancar, melakukan selfie atau menikmati sunset di sore hari.

Menikmati sunset menjadi aktivitas yang sering dilakukan sebanyak 43,5\%. Hal ini dapat terjadi karena Kuta Selatan merupakan daerah Pantai yang dikelilingi oleh tebingtebing batu kapur yang sangat menarik. Di sisi lain menikmati sunset diatas ataupun dibawah tebing ataupun menikmati sunset di bar atau café disekitar pantai yang ada di Kuta Selatan merupakan hal yang memang sering dilakukan oleh wisatawan millennial yang berkunjung ke Kuta Selatan.

Lebih didominasi oleh wisatawan yang baru pertama kali berkunjung sebanyak $45 \%$. Hal ini dapat terjadi karena Kuta Selatan merupakan daya tarik wisata yang mulai 
berkembang dan mulai dikenal oleh wisatawan. Perkembangan teknologi dan banyaknya postingan foto yang ada pada media sosial menjadi hal yang menarik wsiatawan millennial yang tergolong wisatawan first timer untuk mencoba, mengenal, menikmati dan menghabiskan waktu luang yang dimilikinya untuk berkunjung ke Kuta Selatan.

Terakhir, lebih sering mendapat informasi mengenai Kuta Selatan melalui media sosial sebanyak $61 \%$. Hal ini terjadi karena wisatawan millennial memang lebih cenderung menggunakan sebuah media sosial ataupun website tertentu untuk mengetahui informasi dari tempat wisata yang ingin dikunjungi.

\section{Faktor Pendorong}

Berdasarkan analisis faktor yang telah dilakukan maka faktor Pendorong wisatawan millennial berkunjung ke Kuta Selatan adalah sebagai berikut:

1. Faktor pertama memiliki nilai eigenvalue sebesar 4,370 yang diberi nama mencoba gaya hidup baru. Adapun faktor mencoba gaya hidup baru terdiri atas lima indikator yaitu merasakan suasana yang lain dari tempat tinggal, melakukan interaksi dengan masyarakat lokal di tempat wisata, menikmati sesuatu yang baru dan menarik, mengunjungi tempat yang belum pernah dikunjungi, melihat dan mencoba gaya hidup baru dan berbeda.

2. Faktor kedua memiliki nilai eigenvalue sebesar 1,785 yang diberi nama melepaskan diri dari rasa jenuh. Adapun faktor melepaskan diri dari rasa jenuh terdiri atas tiga indikator yaitu melepaskan diri dari rasa jenuh, melepaskan diri dari rutinitas sehari-hari dan ingin merasa relax, fresh, segar dan memanjakan diri.

3. Faktor ketiga memiliki nilai eigenvalue sebesar 1.731 yang diberi nama teman atau keluarga. Adapun faktor teman atau keluarga terdiri atas tiga indikator yaitu untuk menceritakan pengalaman berkunjung kepada keluarga atau teman, mengunjungi teman atau keluarga, dan mengunjungi tempat wisata yang dikunjungi oleh keluarga atau teman.

4. Faktor terakhir atau faktor keempat memiliki nilai eigenvalue sebesar 1.171 yang diberi nama faktor meningkatkan harga diri. Adapun faktor meningkatkan harga diri terdiri atas tiga indikator yaitu menyalurkan hobi travelling, meningkatkan harga diri, dan untuk menunjukan eksistensi diri dengan mengunjungi tempat yang sedang viral atau populer.

\section{Faktor Penarik}

Berdasarkan analisis faktor yang telah dilakukan maka faktor Penarik wisatawan millennial berkunjung ke Kuta Selatan adalah sebagai berikut:

1. Faktor pertama memiliki nilai eigenvalue sebesar 6,788 yang diberi nama viralnya Kuta Selatan. Adapun faktor viralnya Kuta Selatan terdiri atas tujuh indikator yaitu variasi daya tarik wisata yang ada, kelengkapan fasilitas di Kuta Selatan, ketersediaan informasi mengenai Kuta Selatan melalui media sosial, kemudahan akses ke Kuta Selatan, ulasan yang menarik tentang Kuta Selatan di media sosial, rekomendasi dari wisatawan yang sudah pernah berkunjung, dan viralnya Kuta Selatan melalui media sosial.

2. Faktor kedua memiliki nilai eigenvalue sebesar 2,677 yang diberi nama budaya dan tradisi. Adapun faktor budaya dan tradisi terdiri atas empat indikator yaitu melihat budaya dan tradisi yang berbeda, mengunjungi bangunan bersejarah atau Pura-Pura yang ada, mempelajari bahasa dan budaya setempat, dan ketersediaan paket wisata lokal di sekitar kawasan Kuta Selatan.

3. Faktor ketiga memiliki nilai eigenvalue sebesar 1,968 yang diberi nama harga. Adapun faktor harga terdiri atas tiga indikator yaitu harga masuk ke daya tarik wisata yang terjangkau, harga aktivitas wisata yang terjangkau, dan harga makanan dan minuman yang terjangkau.

4. Faktor keempat memiliki nilai eigenvalue sebesar 1,184 yang diberi nama variasi hiburan malam. Adapun faktor variasi hiburan malam terdiri atas lima indikator yaitu menikmati variasi hiburan malam yang ada, menikmati variasi shopping mall dan café-café di sekitar Kuta Selatan, mengunjungi daya tarik wisata yang viral, mengunjungi event-event tertentu di Kuta Selatan, dan mengunjungi spot instagramable.

5. Faktor terakhir atau faktor kelima memiliki nilai eigenvalue sebesar 1,033 yang diberi nama faktor udara bersih dan sejuk. 
Adapun faktor udara bersih dan sejuk atas dua indikator yaitu udara yang bersih dan sejuk, dan cuaca yang bersahabat.

\section{Faktor Dominan}

Adapun faktor yang dominan mendorong wisatawan millennial berkunjung ke Kuta Selatan adalah faktor mencoba gaya hidup baru. Hal ini dapat dilihat melalui nilai eigenvalue tertinggi dalam analisis faktor yaitu sebesar 4,370. Hal ini dapat dijelaskan bahwa gaya hidup yang dilihat oleh wisatawan merupakan gaya hidup dari segi kebiasaan unik dan tradisional yang didapatkan oleh wisatawan saat berkunjung ke Kuta Selatan, gaya hidup dan suasana yang ada di Kuta Selatan berbeda dengan negara asalnya, salah satunya yakni keramahtamahan yang ditunjukkan serta kemudahan berinteraksi dengan masyarakat lokal Bali, selain itu wisatawan juga lebih suka untuk menikmati tempat wisata yang indah dan menarik dan penuh dengan unsur budaya yang tentunya berbeda dengan di Negara asalnya. Hasil ini sama dengan dengan hasil studi yang dilakukan oleh Parhusip (2018) yang berjudul "Wisatawan Milenial di Bali". Dimana pada studi tersebut mendapat hasil bahwa faktor yang paling dominan mendorong wisatawan millennial untuk berkunjung ke Bali adalah faktor novelty and knowledge seeking dimana motivasi wisatawan milenial yang datang ke Bali cenderung didorong oleh keinginan untuk mencari pengetahuan mengenai berbagai hal saat berkunjung ke Bali, mencari sesuatu yang menarik serta untuk bersenang-senang. Sedangkan pada studi saat ini wisatawan millennial yang berkunjung untuk merasakan gaya hidup baru yang berbeda dengan derah asalnya dan menikmati sesuatu yang baru dan menarik.

Adapun faktor yang dominan menarik wisatawan millennial berkunjung ke Kuta Selatan adalah faktor viralnya Kuta Selatan. Hal ini dapat dilihat melalui nilai eigenvalue tertinggi dalam analisis faktor yaitu sebesar 6,788. Dapat dijelaskan bahwa faktor viralnya Kuta Selatan yang dimaksud yakni Kuta Selatan dikatakan memiliki variasi daya tarik wisata yang menarik seperti pantai pasir putih yang dipenuhi tebing atau bebatuan besar yang terletak disekitar pantai salah satunya, selanjutnya banyaknya terdapat informasi mengenai Kuta Selatan melalui instagram dan media sosial hal ini menunjukkan bahwa wisatawan mudah untuk mengakses informasi terkait dengan gadjet yang dimilikinya, dan juga cepatnya informasi yang tersebar melalui unggahan foto menggunakan sosial media dan instagram sehingga wisatawan yang melihat instagram merasa tertarik untuk berkunjung dan secara tidak sengaja hal ini juga merupakan komponen dari Electronic Word of Mouth yaitu proses penyebaran berita dari mulut ke mulut namun melalui media digital atau media sosial yang ada. Hasil faktor viralnya Kuta Selatan berbeda dengan hasil studi yang dilakukan oleh Parhusip (2018) yang berjudul "Wisatawan Milenial di Bali". Dimana pada studi tersebut mendapat hasil bahwa faktor penarik yang mendominasi wisatawan millennial untuk berkunjung ke Bali adalah faktor Cleanliness \& Variety Attraction dimana faktor kebersihan, keindahan alam Bali, dan budayanya menjadi hal yang mampu menarik wisatawan untuk berkunjung ke Bali. Sedangkan pada studi saat ini adalah faktor variasi daya tarik wisata, fasilitas yang ada, berbagai macam content, ulasan serta unggahan media sosial dan yang terakhir ketersediaan berbagai macam informasi mengenai Kuta Selatan melalui media sosial menjadi faktor yang menarik wisatawan millennial berkunjung ke Kuta Selatan.

\section{SIMPULAN DAN SARAN Simpulan}

Karakteristik wisatawan millennial yang berkunjung ke Kuta Selatan lebih didominasi oleh wisatawan asal Jerman sebesar 18\% untuk wisatawan mancanegara dan $19 \%$ untuk wisatawan nusantara yang berasal dari Jawa Timur, yang paling banyak menurut jenis kelaminnya adalah perempuan sebesar 53\%, berstatus masih belum menikah sebanyak $86,5 \%$, berusia 19 sampai 25 tahun sebanyak $69 \%$, lebih banyak bekerja sebagai pelajar sebesar 57\%, memiliki pendidikan terakhir sebagai siswa SMA/SMK sebanyak 55,5\%, lama berlibur lebih dari 7 hari sebesar $65 \%$, besar pengeluaran perhari kurang dari $\mathrm{Rp}$. 500.000 sebesar 43,5\%, lebih banyak menggunakan homestay sebagai tempat menginap sebesar 31,5\%, lebih banyak menginap di daerah Kuta sebesar 24\%, lebih memilih untuk menggunakan sepeda motor saat berkunjung ke Kuta Selatan sebesar $62,5 \%$, Pantai Dreamland menjadi daya tarik 
wisata terfavorit dengan pilihan sebanyak $20 \%$, menikmati sunset menjadi aktivitas yang sering dilakukan sebanyak 43,5\%, lebih didominasi oleh wisatawan yang baru pertama kali berkunjung sebanyak $45 \%$, dan lebih sering mendapat informasi mengenai Kuta Selatan melalui media sosial sebanyak $61 \%$.

Faktor Pendorong wisatawan millennial berkunjung ke Kuta Selatan telah menghasilkan empat faktor dari 14 indikator yang ada didalamnya. Adapun faktor tersebut adalah Faktor pertama mencoba gaya hidup baru, faktor kedua melepaskan diri dari rasa jenuh, faktor ketiga teman atau keluarga, dan faktor keempat meningkatkan harga diri.

Faktor Penarik wisatawan millennial berkunjung ke Kuta Selatan telah menghasilkan lima faktor dari 21 indikator yang ada didalamnya. Adapun faktor tersebut adalah Faktor pertama viralnya Kuta Selatan, faktor kedua budaya dan tradisi, faktor ketiga harga, faktor keempat variasi hiburan malam, dan faktor yang kelima diberi nama udara bersih dan sejuk

Faktor dominan yang mendorong wisatawan millennial berkunjung ke Kuta Selatan dapat dlihat melalui nilai eigenvalue terbesar dalam analisis faktor yaitu sebesar 4.370. Berdasarkan hasil studi yang dilakukan maka yang menjadi faktor pendorong paling dominan dalam penelitian ini adalah faktor mencoba gaya hidup baru.

Faktor dominan yang menarik wisatawan millennial berkunjung ke Kuta Selatan dapat dilihat melalui nilai eigenvalue terbesar dalam analisis faktor yaitu sebesar 6,788 . Berdasarkan hasil studi yang dilakukan maka yang menjadi faktor penarik paling dominan dalam studi ini adalah faktor viralnya Kuta Selatan.

\section{Saran}

Melihat gaya hidup modern yang terdapat pada beberapa tempat di Kuta Selatan yang didominasi oleh berbagai macam bar, café, hiburan malam yang ada maka kedepannya perlu sering diadakan sebuah festival atau event-event baik itu mengenai budaya, gaya hidup ataupun light festival tradisional Bali sehingga wisatawan mancanegara maupun wisatawan nusantara bisa berbaur dan menikmati suasana hiburan modern dengan unsur tradisional Bali sehingga wisatawan lebih menikmati sesuatu yang baru dan menarik, dan gaya hidup baru yang berbeda dengan yang dimiliki oleh tempat asal wisatawan millennial tersebut.

Diharapkan daya tarik wisata yang ada di Kuta Selatan untuk memberikan inovasi berupa aktivitas wisata baru yang menarik dan mampu membuat wisatawan yang berkunjung dan menikmati atraksi serta aktivitas wisata yang ditawarkan seperti aktivitas wisata air yang perlu ditambahkan terutama di sekitar pantai Dreamland, dan Labuan sait, serta adanya aktivitas ke pasar malam tradisional Bali di kuta Selatan sehingga menjadi lebih berkesan, dan dapat mnjadi pengalaman yang baru sehingga muncul niat dari wisatawan tersebut untuk berkunjung kembali ke Kuta Selatan.

Pemerintah maupun pengelola daya tarik wisata di Kuta Selatan untuk lebih memperkenalkan dan mempromosikan serta memberikan informasi yang lebih detail tentang berbagai atraksi wisata yang disediakan melalui media sosial seperti instagram, facebook, trip advisor dan lainnya. Sehingga mampu mempengaruhi minat calon wisatawan untuk berkunjung be Bali pada umumnya dan Kuta Selatan pada khususnya.

Studi ini tentunya memiliki kelemahan terkait dengan berbagai aspek yang diteliti. Maka dari itu, untuk kedepannya diharapkan studi selanjutnya disarankan untuk melakukan studi mengenai pola perjalanan wisatawan millennial di Kuta Selatan atau studi tentang keputusan wisatawan millennial untuk membeli sebuah aktivitas wisata yang ditawarkan di Kuta Selatan. 


\section{Kepustakaan}

Baharuddin \& Wahyuni, E. N. (2008). Teori Belajar dan Pembelajaran. Yogyakarta: Ar-ruzz Media.

Ghozali, Imam. 2005. Aplikasi Analisis Multivariate dengan SPSS. Semarang: Badan Penerbit UNDIP.

Goyette, et al, 2010, E-Wom : Word of Mouth Measurement Scale for E-Service Context, Journal of Administrative Sciences, Volume 27: 5-23.

Hair, et al. 2006. Multivariate Data Analysis $6^{\text {th }} E d$. New Jersey : Pearson Education.

Lay, Olivia Dianti. 2013. Faktor Pendorong dan Faktor Penarik Wisatawan Surabaya Melakukan Perjalanan Wisata Ke Penang, Malaysia. Jurnal Tourism Retailing. Vol. 2, 2013.

Parhusip, Nina Ester. 2018. Wisatawan Milenial di Bali (Karakteristik, Motivasi, dan Makna Berwisata). Jurnal Destinasi Pariwisata, Vol. 6 no. 2, 2018.

Ryder, N. B. (1965). The Cohort as a Concept in the Study of Social Change. American Sociological Review, 30 (6), 843-861. https://doi.org/10.2307/2090964.

Schiffman, Leon, G.,Leslie Lazar Kanuk, 2000, Consumer Behavior, Edisi Tujuh, Prentice-Hall, New Jersey.

Sutrisno, Edy. 2013. Manajemen Sumber Daya Manusia, Cetakan Kelima. Yogyakarta: Prenada Media.

Yuan, S dan McDonald, C. 1990. Motivational Determinates of International Pleasure Time. Jurnal Travel Research, 24(1), 42-44. 